DOI: https://doi.org/10.32839/2304-5809/2021-11-99-37

УДК 336.72

Жучкова В.Ю.

Харківський національний педагогічний університет імені Г.С. Сковороди

\title{
ФОРМИ, МЕТОДИ ТА ПРИЙОМИ КОРЕКЦІЇ НАВИЧОК САМОРЕГУЛЯЦІЇ У МОЛОДШИХ ШКОЛЯРІВ
}

\begin{abstract}
Анотація. Розглянуто питання саморегуляції в психолого-педагогічній літературі та їі розвиток у молодшому шкільному віці. Досліджено особливості та різноманітність форм, методів та прийомів корекції навичок саморегуляції у молодших школярів, використання яких можливе під час навчально-виховного процесу. Описано ефективність активних методів навчання, корекційних ігор та групової форми роботи для корекції навичок саморегуляції. Обгрунтовано, що вони допоможуть дітям молодшого шкільного віку правильно реагувати на стресові ситуації, вміти виходити із конфліктних ситуацій; правильно висловлювати свої почуття та розуміти, що відчувають люди, що їх оточують; формувати навички едективного спілкування; спрямовані на зменшення шкільної тривожності, збереження психічного здоров'я дітей та формування саморегулящії.
\end{abstract}

Ключові слова: саморегуляція, порушення саморегуляції, фрактори саморегуляції, навички, навички саморегуляції, молодші школярі, форми, методи та прийоми корекції, корекційні ігри.

Zhuchkova Viktoriia

Kharkiv National Pedagogical University named after G.S. Skovoroda

\section{FORMS, METHODS AND METHODS OF CORRECTION OF SELF-REGULATION SKILLS IN JUNIOR SCHOOLCHILDREN}

Summary. The issue of self-regulation in the psychological and pedagogical literature and its development in primary school age is considered. The peculiarities and variety of forms, methods and techniques of correction of self-regulation skills in junior schoolchildren, the use of which is possible during the educational process, have been studied. The effectiveness of active teaching methods, correctional games and group work for the correction of self-regulation skills is described. The problem of self-regulation in psychology is one of the most important both in terms of theoretical consideration and in terms of experimental research. In the life of each person of great importance is the problem of regulating their behavior in conditions that change according to the surrounding reality. The development of self-regulation skills should take place at the physiological, empathic and expressive levels, which determines the effectiveness of such methods in work as active work with icons and other visual materials, playful play of situations, role-playing, psychogymnastics, method of "general storytelling", exercises. It is substantiated that they will help children of primary school age to react correctly to stressful situations, to be able to get out of conflict situations; correctly express their feelings and understand how people around them feel; to form skills of effective communication; aimed at reducing school anxiety, maintaining the mental health of children and the formation of self-regulation. The problem of developing skills of self-regulation in primary school age in the educational process, namely the forms, methods and techniques of its correction today remains relevant in both theoretical and practical terms, as there is an ambiguous understanding of its essence, place in the pedagogical process. The purpose of the article. The main purpose of this work is to study the features of forms, methods and techniques of correction of self-regulation skills in primary school children. The need for special work with children of primary school age in order to develop their skills of emotional and volitional components of self-regulation, as well as the component of action regulation.

Keywords: self-regulation, violation of self-regulation, factors of self-regulation, skills, skills of self-regulation, junior schoolchildren, forms, methods and techniques of correction, correctional games.

$\Pi^{\circ}$ остановка проблеми. В даний час успіх людини визначається її особистісними особливостями. Вона самостійно приймає рішення, прагне саморозвитку. Важливу роль відіграє здатність до саморегуляції своєю поведінкою за допомогою свідомості, яка передбачає самостійність людини не тільки в прийнятті рішення, а й у ініціації дій, їх здійсненні та контролі.

Здатність до саморегулящії визначається віковими особливостями та сенситивним періодом. Найбільш важливим періодом для розвитку саморегулящії $є$ молодший шкільний вік, так як у цей час у дитини починають формуватися довільні розумові дії: навмисне запам'ятовування та пригадування навчального матеріалу, довільна увага, спрямована на стійке спостереження, завзятість у вирішенні розумових задач. Потреби соціального середовища, ставлять перед нами завдання виховання та навчання активної особистості, наділеної самостійністю та саморегуляцією.

Дуже важливо починати вивчення саморегуляції саме у молодшому шкільному віці. Оскільки в онтогенезі саморегулящія починає формуватися у зв'язку з необхідністю підкорятися вимогам дорослих, правила поведінки у суспільстві, при включенні до навчальної діяльності. Саморегуляція $є$ новоутворенням молодшого шкільного віку.

Здатність до саморегулящії відіграє важливу роль в організації складних форм довільної діяльності, до яких насамперед належить навчання. Для здійснення навчальної діяльності необхідні вміння зосередити увагу, активно сприймати та запам'ятовувати інформацію, попередньо орієнтуватися в умовах завдання та продумувати хід рішення, звіряти отриманий результат з заданим зразком та пред'явленими умовами. 
Розвиток саморегулящії одна із центральних ліній розвитку дітей. Різноманітність видів діяльності, які освоюе школяр, поєднуе одне - у них формуеться найважливіше особистісне новоутворення цього віку - довільне регулювання поведінки та діяльності, здатність до самоконтролю.

Аналіз останніх досліджень і публікацій. Проблемі саморегуляції присвячені роботи багатьох психологів (К. Бернер, Л. С. Виготський, В. К. Калін, В. Мішель, О. О. Конопкін, I. Ч. Шеррінгтон).

Уявлення про людину як самоактуалізуючу, організовану систему виводить на перший план такі поняття, як «особистість», «саморегуляція». Взаемозв'язок між ними відображае термін «особистісна саморегуляція». Вивчаючи саморегуляцію надають значення особистісним проявам - А. Бандура, Л. І. Божович, Б. Б. Коссов, Р. Олпорт, Дж. Роттер, О. І. Щербаков, З. Фрейд, В. О. Отрут. Дослідженню особистісних структурних компонентів відводили провідну роль психологічним механізмам регулювання життедіяльності - А. Адлер, Л. І. Анциферова, Б. С. Братусь, Б. П. Паригін, О. В. Петровський, В. І. Слободчиков, З. Фрейд.

Дослідженням саморегуляпії дітей молодшого шкільного віку займалися О. О. Данилова, Т. В. Драгунова, А. В. Захарова, А. К. Маркова, Н. С. Лейтес та інші. Вони розглядали даний період як найбільш чутливий до самозміни, саморозкриття, до зовнішніх навчальних та виховних впливів.

У роботах, присвячених вивченню дітей, саморегуляція розглядалася або в контексті вивчення інших психічних функцій та процесів (Т. В. Сгорова, В. І. Лубовський, Н. Г. Лутонян, О. С. Орлова), або в окремому її прояві як функції самоконтролю (С. Б. Аксьонова, С. Д. Максименко).

Виділення не вирішених раніше частин загальної проблеми. Однак проблема розвитку навичок саморегуляції у молодшому шкільному віці у освітньому процесі, а саме форм, методів та прийомів ії корекції на сьогодні залишаеться актуальною як у теоретичному, так і практичному плані, оскільки спостерігаеться неоднозначне розуміння її сутності, місця в педагогічному процесі.

Мета статті. Головною метою ціеї роботи $\epsilon$ дослідження особливостей форм, методів та прийомів корекції навичок саморегуляції у молодших школярів.

Виклад основного матеріалу. Проблема саморегуляції у психології $є$ однією з найважливішою як у плані теоретичного розгляду, так і в плані експериментальних досліджень. У життедіяльності кожної людини велике значення має проблема регуляції своеї поведінки в умовах, що змінюються згідно навколишньої дійсності. Тому, у зв'язку з актуальністю дано проблематики, останнім часом у психології стрімко розвиваються дослідження волі, емоцій та емоційно-вольового регулювання (Л. С. Виготського, С. Л. Рубінштейна, О. М. Леонтьєва, В. А. Іванникова О. В. Дашкевич, М. В. Чумакова) [3, с. 57].

Поняття "саморегуляція» (лат. Regulare - упорядковувати, налагоджувати) означає процес управління людиною власними психологічними та фрізіологічними станами, а так само вчинками [2, с. 47].

Поняття регулящії вперше запровадив П. Жане, стверджуючи, що здатність до саморе- гулящії е найвищим критеріем розвитку особи. Саморегуляція розглядалася ним як процес опосередкування соціальних норм та цінностей, як система внутрішніх вимог, які перетворюють людину на активного суб'єкта [1, с. 12].

Д. І. Фельдштейн у концепції логотерапії спеціально виділяе смислове регулювання поведінки, маючи на увазі під нею пошук і прийняття того чи іншого сенсу життя, яким має бути пронизане будь-яке життева подія [4, с. 31].

Поняття саморегуляції в психологічній науці часто ототожнюють з самоврядуванням, волею та самоконтролем. Г. С. Нікіфоров вважае, що у сучасної психології ще склалося задовільного тлумачення поняття самоврядування та саморегулювання. Нерідко вони використовуються як синоніми.

У зарубіжних дослідженнях поняття саморегуляції переважно вивчалося через поняття «особистість», «особистісна саморегуляція». Особистість у взаемозв'язку 3 саморегуляцією розглядалася А. Бандурою, В. Вундтом, К. Роджерсом. Для характеристики процесу особистісного розвитку К. Роджерс запровадив поняття «Я-концепція». На його думку, ступінь задоволеності людини життям і собою залежить від того, наскільки узгоджуеться між собою його «реальне Я» та «ідеальне Я». По суті, він пояснюе механізм адаптації, вважаючи їі найважливішою умовою здійснення самоактуалізації. О. Бандурою було виділено дві групи факторів саморегуляції, які мають вплив одне на одного - зовнішні та внутрішні. Як зовнішні фактори саморегуляції О. Бандура виділяе стандарти, за якими ми можемо оцінювати свою поведінку. Внутрішні чи особистісні фоктори саморегуляції у світлі концепції Системи «я» Бандура розглядае набагато докладніше, виділяючи три необхідні умови: самоспостереження (self-observation), процес винесення суджень (judgmentalprocess) і активна реакція на себе (activeself-reaction) (Кондратьев М. Ю., Ільїн Ст.А.) [1, с. 23].

Порушення саморегуляції - це неможливість цілеспрямованої організації своїх розумових дій. Саме тому в своїй роботі психолог, логопед та вчитель має використовувати набір різноманітних форм, методів та прийомів для ï корекції.

Одним із прийомів, що активізують процес сприйняття $є$ порівняння досліджуваних об'єктів. На кожному уроці плануеться корекційна робота у формі ігор, які спеціально призначені для активізації психічних процесів, розвитку розумових здібностей, тренування пам'яті та мислення дітей. Ігри, що розвивають, допомагають краще засвоювати і закріплювати отримані знання, виховують у дітей з низькою інтелектуальною активністю спостережливість.

Активні методи навчання (AMO) - це система методів, що забезпечують активність та різноманітність розумової та практичної діяльності учнів у процесі освоєння навчального матеріалу. Вони будуються на практичній спрямованості, ігровому дійстві та творчому характері навчання, інтерактивності, різноманітних комунікаціях, груповій формі організації їхньої роботи.

АМО будуються на:

- Використанні знань та досвіду учнів;

- Залученні до процесу всіх органів чуття; 
- груповий формі організації їх роботи;

- діяльнісному підході до навчання;

- різноманітних комунікаціях;

- творчому характері навчання;

- практичній спрямованості;

- діалозі і полілозі;

- інтерактивності;

- грі;

- рефрлексіі;

- pyci.

Виховання та навчання молодших школярів при всьому різноманітті підходів, обумовлених своєрідністю їхньої фрізичної та психічної сфрери, має ряд загальних методів:

- методи фрормування знань;

- методи виховання особистості;

- методи організації взаємодії педагога та які займаються;

- методи регулювання психічного стану дітей.

В основі їх лежать закономірності навчання, вікового розвитку, дидактичні та спеціально-методичні засади, корекційна спрямованість педагогічного процесу.

Прийоми психолого-педагогічної регулящії:

1) Доброзичливий стиль спілкування, довіра, відкритість педагога, виражена увага до кожного учня;

2) позитивний настрій, позитивна мотивація, підтримання оптимізму, емоційного комфорту та безпеки;

3) постановка спільної мети, об'єднання загальними інтересами, організащія взаємодій учнів за принципом психологічної сумісності;

4) адекватність засобів, методів та методичних прийомів реального стану та індивідуальних можливостей дітей;

5) акти примирення у разі кондрліктів, що виникають внаслідок нестійкого психічного стану, невдачі, болю, різних думок, емоційного дискомфорту, відсутності уваги. Способами вирішення конфрлікту можуть бути мотивоване переконання, зміна установок, відносин та оцінок, компроміс, уступки, жарт, посмішка, обопільний аналіз ситуації, концентрація на позитивному, переорієнтування уваги на інший об'єкт або дію;

6) сугестивні методи (методи навіювання), у яких діти з низькою інтелектуальною активністю без обмірковування, пасивно, без боротьби мотивів засвоюють ідеї та висловлювання педагога (психолога). Навіювання стосуються зняття страхів, тривоги, стресу, невпевненості, підвищення працездатності, мобілізації емоційної активності;

7) використання музики 3 метою зняття нервово-м'язової напруги, прискорення відновлювальних процесів, ритмічного та емоційного налаштування;

8) ігрові методи організації занять, що активізують увагу, пам'ять, уяву, створюють відчуття задоволення, радості. Спеціальним підбором рухливих ігор можна регулювати психоемоційний стан від зняття агресивності до формування емпатії у міжособистісних відносинах;

9) театралізовані форми занять (казкотерапія, сюжетно-рольові ігри, тематичні ігрові композиції), пов'язані з пересуванням, відтворенням позитивних образів, спільною діяльністю, які можуть стати опорою наслідування, джерелом рухової, психомоторної, соціальної активності.
Для успішнішого конструювання процесу розвитку навичок саморегуляції молодших школярів необхідно також враховувати те що, що заняття має бути добре структуровано з урахуванням психоемоційної напруги, вікових особливостей (оптимальні за часом для сприйняття) і включати різноманітні за інтенсивністю фізичної активності види діяльності.

На думку Н. П. Слободняк, заняття не має перевищувати 40 хвилин (час одного шкільного уроку, яке вважається оптимальним для ціеї вікової групи), а кількість осіб у групі - 10-12 дітей. Оптимальна періодичність зустрічей - 1-2 рази на тиждень. Слід дотримуватись послідовності тем і враховувати час на закріплення набутих навичок. Також автор пропонує поєднувати сюжети історій та оповідань ігровим персонажем, разом 3 яким діти засвоюватимуть прийоми саморегулящії [1, с. 15].

Необхідно також відзначити зміст та структуру самого заняття. Наприклад, Л. Р. Мутагарова пропонує наступну структуру заняття: у вступній частині заняття використовувати елементи методів активного навчання 3 метою емоційного настрою на урок, розвитку тактильного спілкування та довіри один до одного, а при повідомленні мети та завдань актуалізувати увагу на відчуттях, пов'язаних з настроем, робити установку створення власного позитивного настрою 3 допомогою міміки. Тут можливе коротке освітлення теоретичного матеріалу.

У практичній частині заняття дощільно використовувати статичні, динамічні та рольові завдання. Необхідно також додати мімічні вправи, дихальну гімнастику, ритмопластику, рухливі ігри із застосуванням «сюжетної візуалізації». На практиці, нами була розроблена і використана авторська програма, в яку входять ігри. Наприклад, ігри «Надоїдлива муха»: їі мета - вчити концентруватися на окремих частинах свого тіла, контроль за дрібними рухами. Дітям пропонуеться уявити, що вони лежать на пляжі, сонечко пригріває, ворушитися не хочеться. Раптом муха прилетіла і сіла на лоб. Щоб прогнати муху, потрібно поворухнути бровами. Муха кружлятиме навколо очей - поморгати ними. Перелетіла на щоку, потім на іншу - поворушити губами, надути щоки. Сіла на підборіддя - поворушити щелепою.

Гра «Повтори ритм». Мета: розвиток довільної уваги та контролю рухової активності. Дорослий відстукуе (проплескуе) будь-який ритмічний малюнок, дитина повинна його повторити. Дитина може слухати ритм із заплющеними очима. Потім ведучим стає дитина. Наприкінці гри дітям запитують: «Що було легше: задавати ритм чи повторювати?».

Корекщійні ігри на стимулювання поведінки, наприклад, "Хвилина пустощів» (психологічне розвантаження). Психолог за сигналом (удар в бубон) пропонуе дітям пустувати: кожен робить те, що йому хочеться - стрибає, бігає, танцюе. Повторний сигнал через 1-3 хвилини оголошуе кінець пустощам.

Гра «Очі у вічі» (Кряжева Н.Л.). Мета: розвивати у дітях почуття емпатії, налаштувати на спокійний лад. Психолог просить дітей взятися за руки зі своїм сусідом по парті, а потім подивитися один одному тільки в очі i, відчуваючи руки, спро- 
бувати мовчки передавати різні стани: «я сумую», "мені весело, давай грати», "я розсерджений», «не хочу ні 3 ким розмовляти». Після гри проходить обговорення з дітьми, які стани передавалися, які з них легко відгадувати, а які важко [4].

У заключній частині рекомендуеться використовувати ігри на відновлення дихання, робити аналіз проведених ігор та рефлексію. В результаті таких занять, на думку автора, що поєднують рухомі та малорухливі прийоми емоційної саморегуляції, діти навчаються досягати трьох основних едектів: заспокоєння, відновлення та активації [3, с. 47].

Провівши аналіз підходів до розвитку навичок саморегуляції можна зробити висновок, що розвиток навичок саморегулящії має відбуватися на фрізіологічному, емпатійно-чуттевому та експресивному рівнях, що визначає ефрективність таких методів у роботі, як активна робота 3 піктограмами та іншими наочними матеріалами, ігрове програвання ситуацій, розігрування етюдів за ролями, психогімнастика, метод «загального оповідання історій», вправи.

Вивчивши основні змістовні аспекти, можна зробити висновок, що найбільша едективність групової форми роботи може спостерігатися в групах 8-12 осіб, при витримці певної структу- ри заняття, де вправи чергуються між собою для найбільш ефрективного сприйняття. Слід зазначити, що можливість розвитку навичок шляхом таких занять $€$ едрективним і швидким способом, а отже, можна припустити, що використання спеціальних вправ в освітньому процесі можуть сприяти розвитку навичок саморегуляції.

Висновки. Таким чином, необхідність проведення спеціальної роботи 3 дітьми молодшого шкільного віку з метою розвитку у них навичок емоційного та вольового компонентів саморегуляції, а також компонента регуляції дії обумовлена тим, що віковий період 6-8 років є сензитивним для фрормування емоційної та вольової сфрери. Різноманітність форм, прийомів та методів корекції навичок саморегуляції молодших школярів, зокрема її емоційного, вольового компонентів та компонента регулящії дії у молодших школярів спрямована на допомогу дітям навчитися правильно, реагувати на стресові ситуації, вміти виходити їх виникаючих конфліктів; допомогти правильно висловлювати свої почуття та розуміти, що відчувають люди, що їх оточують; формувати навички едективного спілкування; спрямована на зменшення шкільної тривожності, збереження психічного здоров'я дітей та фpopмування саморегуляції.

\section{Список літератури:}

1. Божович Л.І., Морозова Н.Г., Славіна Л.С. Психологічний аналіз значення позначки як мотиву навчальної діяльності школярів. Психологія у вузі. 2008. № 5. С.121-150.

2. Завгородня О.В. Проблема психологічного здоров'я: спроба теоретичного аналізу. Практична психологія та соціальна робота. 2007. № 1. С. 55-60.

3. Психологічна допомога: від кризи до ресурсу. Матеріали III Всеукраїнського науково-практичного форуму (21-26 квітня 2020 року, м. Суми) / за заг. ред. А.В. Вознюк. Суми : НВВ КЗ СОІППО, 2020. С. 182.

4. Седова Е.О. Этапы сенсомоторной коррекции в развитии саморегуляции у младших школьников. Психология. Психобизиология. 2014. № 3. URL: https://cyberleninka.ru/article/n/etapy-sensomotornoy-korrektsii-vrazvitii-samoregulyatsii-u-mladshih-shkolnikov (дата звернення: 27.10.2021).

\section{References:}

1. Bozhovich L.I., Morozova N.G., Slavina L.S. (2008) Psykholohichnyy analiz znachennya poznachky yak motyvu navchal'noyi diyal'nosti shkolyariv [Psychological analysis of the meaning of the mark as a motive for educational activities of students]. Psykholohiya u vuzi, no. 5, pp. 121-150.

2. Zavhorodnya O.V. (2007) Problema psykholohichnoho zdorov'ya: sproba teoretychnoho analizu [The problem of psychological health: an attempt at theoretical analysis]. Praktychna psykholohiya ta sotsial'na robota, no. 1, pp. $55-60$

3. Voznyuk A.V. (ed.) (2020) Psykholohichna dopomoha: vid kryzy do resursu. Materialy III Vseukrayins'koho naukovopraktychnoho forumu (21-26 kvitnya 2020 roku, m. Sumy) [Psychological help: from crisis to resource. Proceedings of the III All-Ukrainian Scientific and Practical Forum]. Sumy: NVV KZ SOIPPO, pp. 182.

4. Syedova E.O. (2014) Etapy sensomotornoyi korektsiyi v rozvytku samorehulyatsiyi u ditey molodshoho shkil'noho viku [Stages of sensorimotor correction in the development of self-regulation in primary school children]. Psykholohiya. Psykhofiziolohiya, no. 3. Available at: https://cyberleninka.ru/article/n/etapy-sensomotornoykorrektsii-v-razvitii-samoregulyatsii-u-mladshih-shkolnikov (accessed 27 October 2021). 